\title{
特集 地形響を受けた風に対するCFDの適用性
}

\section{地形の影響を受ける風における CFD 技術の確立に向けて For Establishment of CFD Technology on Terrain Affected Wind}

本章では，建築基準整備促進事業で実施された，以下 の項目について報告するものとする。

1) 風速の地形による影響評価のための数值流体計算の ベンチマークテストの提示

2) 風速の地形による影響評価のための適切な数值流体 計算方法および計算条件の整備

3）地形による風速の割増評価について代表的な地形の 抽出, 分類, および数值流体計算の実施, さらにはデー タベースの構築

ここで得られた情報は, 今後に向けて, CFD 技術が地 形の影響を受けた風の推定に対して適切に活用されるこ とが期待される。現在,すでにCFD 技術を保有する場合, 地形を対象とする場合には, どのような計算方法を選択 し，計算条件を設定すればよいかを判断するために用い られる。また，保有コードにより地形の問題に対して風 速の特性が適切に推定されるかのベンチマークテストの 方法も提示される。さらには, 代表的な基本形状の地形 における風の特性の変化をデータベースとして, まとめ ることとする。次章において, 実地形を与えられたとき のデータベースの活用方法について検討する。 なお,ここでの成果の課題として,計算条件については, ほぼ妥当な解が得られるためのデータが示されているが, これより解像度が粗い，より計算負荷が小さい計算条件

\author{
岸田岳士 ${ }^{* 1}$ 佐々木亮治*1 田村哲郎*2
}

Takeshi KISHIDA, Ryoji SASAKI, Tetsuro TAMURA
での解の再現性については, 吟味されている訳ではなく, 計算する上でのミニマムの要求条件が示されている訳で はない。また, ベンチマーク方法についても実際に存在 する地形の影響は多種多様であることを踏まえると，三 次元的な流れの回り込みに対する吟味も重要となるが, ここでは，比較的二次元性が顕著な形態の尾根上のもの で, 剥離の有無を中心に検討する参照データが提供され ている。まずはこの段階でのコードチェックの実行を期 待したい。また, 今後の複雑地形での風観測の充実を切 に希望するものである。さらにデータベースとしても地 形の多様性を考えると, 一部の形態について示されてい るだけである。ただし，それでもこのデータを用いた実 地形での風速割増の評価方法については，先に述べたよ うに次章で提案されている。データベースの充実につい ては, 今後の研究成果の蓄積を待ちたい。

1. 計算モデル・計算条件の設定方法

\section{(岸田岳士)}

前章の計算事例を踏まえて，ここでは実在地形周りの 風の計算を適切に行うための計算モデル・計算条件の設 定方法について纏める。前章で実施した解析条件の一覧 を表-1 に示す。

* 1 (株)風工学研究所

Wind Engineering Institute Co., Ltd.

*2 東京工業大学大学院 環境理工学創造専攻 教授 Professor, Department of Environmental Science and Technology, Tokyo Institute of Technology 
表 1 実在地形周りの流孔を対象とした解析の計算条件の一覧

\begin{tabular}{|c|c|c|c|c|c|c|c|c|c|c|}
\hline \multicolumn{2}{|c|}{ 該当する項目 } & 前章 2.3 & \multicolumn{4}{|c|}{ 前章 2.2} & \multicolumn{4}{|c|}{ 前章 2.4} \\
\hline \multicolumn{2}{|c|}{ 手法 } & LES(自作) & \multicolumn{4}{|c|}{ LES(オープンソースコード) } & \multicolumn{4}{|c|}{ LES(オープンソースコード) } \\
\hline \multicolumn{2}{|c|}{ 対象地形 } & いちき串木野 & \multicolumn{4}{|c|}{ いちき串木野 } & \multicolumn{4}{|c|}{ 白滝 } \\
\hline \multicolumn{2}{|c|}{ 格子系 } & 構造(一般座標) & \multicolumn{4}{|c|}{ 非構造 } & \multicolumn{4}{|c|}{ 非構造 } \\
\hline \multicolumn{2}{|c|}{ 境界層要素 層数 } & - & \multicolumn{4}{|c|}{5 層 } & \multicolumn{4}{|c|}{3 層 } \\
\hline \multirow{3}{*}{ 解析領域 } & 風方向 & $20 \mathrm{~km}(33.3 \mathrm{~h})$ & \multicolumn{4}{|c|}{$20 \mathrm{~km}(33.3 \mathrm{~h})$} & \multicolumn{4}{|c|}{$25 \mathrm{~km}(41.7 \mathrm{~h})$} \\
\hline & 風直角 & $5 \mathrm{~km}(8.3 \mathrm{~h})$ & \multicolumn{4}{|c|}{$4 \mathrm{~km}(6.7 \mathrm{~h})$} & \multicolumn{4}{|c|}{$8 \mathrm{~km}(13.3 \mathrm{~h})$} \\
\hline & 鉛直 & $6 \mathrm{~km}(10 \mathrm{~h})$ & \multicolumn{4}{|c|}{$10 \mathrm{~km}(16.7 \mathrm{~h})$} & \multicolumn{4}{|c|}{$8 \mathrm{~km}(13.3 \mathrm{~h})$} \\
\hline \multicolumn{2}{|c|}{ 地形の最高高さ h } & 約 $600 \mathrm{~m}$ & \multicolumn{4}{|c|}{ 約 $600 \mathrm{~m}$} & \multicolumn{4}{|c|}{ 約 $600 \mathrm{~m}$} \\
\hline \multicolumn{2}{|c|}{ 要素数 } & $\begin{array}{c}\text { 約 } 804 \text { 万 } \\
(600 \times 200 \times 67)\end{array}$ & \multicolumn{2}{|c|}{ 約 1440 万 } & \multicolumn{2}{|c|}{ 約 2320 万 } & \multicolumn{2}{|c|}{ 約 1000 万 } & \\
\hline \multirow{3}{*}{ 最小解像度 } & 風方向 & $7.2 \mathrm{~m}$ & \multicolumn{2}{|c|}{$10 \mathrm{~m}$} & \multicolumn{2}{|c|}{$2.5 \mathrm{~m}$} & \multicolumn{2}{|c|}{$20 \mathrm{~m}$} & \multicolumn{2}{|c|}{$10 \mathrm{~m}$} \\
\hline & 風直角 & $7.9 \mathrm{~m}$ & 10 & $\mathrm{~m}$ & & & 20 & & 10 & $\mathrm{~m}$ \\
\hline & 鉛直 & $0.04 \mathrm{~m}$ & $5 n$ & $n$ & & & $5 n$ & $n$ & $5 n$ & $\mathrm{n}$ \\
\hline 地表面境 & 界条件 & キャノピーモデル & \begin{tabular}{l|l} 
滑面 \\
対数則|
\end{tabular} & $\begin{array}{l}\text { 粗面 } \\
\text { 対数則 }\end{array}$ & $\begin{array}{r}\text { キャ } \\
\text { モ }\end{array}$ & $\begin{array}{l}\text { ピー } \\
\text { ル }\end{array}$ & \begin{tabular}{|c|} 
滑面 \\
対数則
\end{tabular} & $\begin{array}{l}\text { 粗面 } \\
\text { 対数則 }\end{array}$ & \begin{tabular}{|c|} 
滑面 \\
対数則
\end{tabular} & $\begin{array}{l}\text { 粗面 } \\
\text { 対数則 }\end{array}$ \\
\hline レイノ & レズ数 & & $6.7 \times$ & $10^{5}$ & & $10^{5}$ & $4.5 \times$ & $10^{5}$ & $4.5 \times$ & $10^{5}$ \\
\hline 流入境甹 & 是条件 & 片岡の方法+粗面吹走 & $\begin{array}{l}\text { 滑面 } \\
\text { Lund }\end{array}$ & $\begin{array}{l}\text { 粗面 } \\
\text { Lund }\end{array}$ & $\begin{array}{l}\text { 滑面 } \\
\text { Lund }\end{array}$ & $\begin{array}{l}\text { 粗面 } \\
\text { Lund }\end{array}$ & \begin{tabular}{l|} 
滑面 \\
Lund
\end{tabular} & $\begin{array}{l}\text { 粗面 } \\
\text { Lund }\end{array}$ & \begin{tabular}{l|} 
滑面 \\
Lund
\end{tabular} & $\begin{array}{l}\text { 粗面 } \\
\text { Lund }\end{array}$ \\
\hline 流入の境甹 & 層厚さ & & $600 \mathrm{~m}$ & $800 \mathrm{~m}$ & $600 \mathrm{~m}$ & $800 \mathrm{~m}$ & $600 \mathrm{~m}$ & $800 \mathrm{~m}$ & $600 \mathrm{~m}$ & $800 \mathrm{~m}$ \\
\hline 乱流モ & デル & ダイナミックスマゴリンスキー & & 榫スマニ & リンスン & & 標準 & Kマ & リンスキ & $=$ \\
\hline
\end{tabular}

\section{【解析領域の大きさの設定】}

・水平方向の解析領域の大きさは, 対象領域（ウィンド ファームなど）の大きさにより変化することとなる。 対象領域と側面境界との距離は, 壁面効果が小さくな るように広めに設定する，あるいは緩衝領域を設定す るなどの方法が考えられる。

・鉛直方向の解析領域の大きさは閉塞率を考慮して設定 することとなり，5\%以下に設定することが望ましい1), 2)。

\section{【地形データ】}

・対象とする地形の起伏形態に応じて地形データの水平 方向解像度を選択寸る必要がある。国土地理院では水 平方向 $10 \mathrm{~m}$ 間隔の地形データが日本のほぼ全域で整備 され，誰もが使用可能な状況にある。また，水平方向 $5 \mathrm{~m}$ 間隔のデータに関しても整備されつつある状況で ある。

\section{【メッシュ形状】}

・地表面境界条件にキャノピーモデルを使用する場合に は，キャノピーを設定する部分に対し鉛直方向にある 一定以上メッシュ分割をする必要があるため，地表近 傍での鉛直方向の格子を細かくする必要がある。 ・非構造格子を用いる場合，急峻な地形に対しては，地 表面に境界層セルを $3 〜 5$ 層程度挿入し，境界層セルは
プリズムメッシュ，その上部はテトラメッシュとする ことが有効である。

【地表面境界条件】

・実在地形を対象とした予測を実施する場合には，地表 面境界条件として $z_{0}$ 型の粗面対数則やキャノピーモデ ルなどの地表粗度を考慮した境界条件を設定する必要 がある。

【土地利用データ】

・対象地点周辺で粗度が変化する場合には，解析に使用 する土地利用データの解像度や粗度高さを考慮するこ とが有効である。

参考文献

1) 建築物の而風設計のための流体計算ガイドブック, 日 本建築学会, 2005, p90

2) 実務者のための建築物風洞実験ガイドブック，日本建 築センター，2008，p97

2. $\mathrm{CFD}$ 検証のためのベンチマークの提案 (佐々木亮治)

2. 1 ベンチマークテスト比較用データ

実在地形における CFD 検証用のベンチマークテスト として，以下の $2 つ の$ 地形を選定した。 
・鹿児島県いちき串木野

\section{・山口県白滝山}

なお, ベンチマークテストにおける比較用のデータと しては，以下の 3 種類の図を用意した。

(1)平均風速コンター図

解析領域における平面的な風速分布の傾向を全体的 に把握することを目的とする。また， 2 種類の高さのコ ンター図（地表面高さ $60 \mathrm{~m}$ と $30 \mathrm{~m}$ ）を用意することで， 鉛直方向における増速および減速の全体的な傾向も確 認できる。

(2)断面位置での地形と風速比

ある鉛直断面における地形（標高）と平均風速の関係 を把握することを目的とする。また，地形形状の変化に 応じた増速および咸速の全体的な傾向を確認する。

(3)断面位置での風速の鉛直分布

ある鉛直断面における風速の鉛直分布の関係を把握する ことを目的とする。上記(2)の断面において, 増速や減速 の傾向がよく表れている地点を対象に, 地形形状の変化 に応じた風速の鉛直分布を確認する。

\section{2 ベンチマークテスト 1 鹿児島県いちき串木野}

\section{(1) 解析条件}

解析対象は，鹿児島県いちき串木野地区とする。解析 結果の検証用となる 2 か所の観測点を図 1 に, 観測点の 緯度経度および標高を表 1 に示す。解析風向は, 図 1 に 示す風向 NNW および風向 SW の 2 風向とする。両風向 とも, 海側から観測点に向けて徐々に標高が高くなる地 形である。また, 図 2 に示す航空写真から分かるように, 本解析領域の陸地部分は, ほぼ森林である。従って, 解 析時においては，この状況を適切に地表面粗度に反映さ せることが必要である。

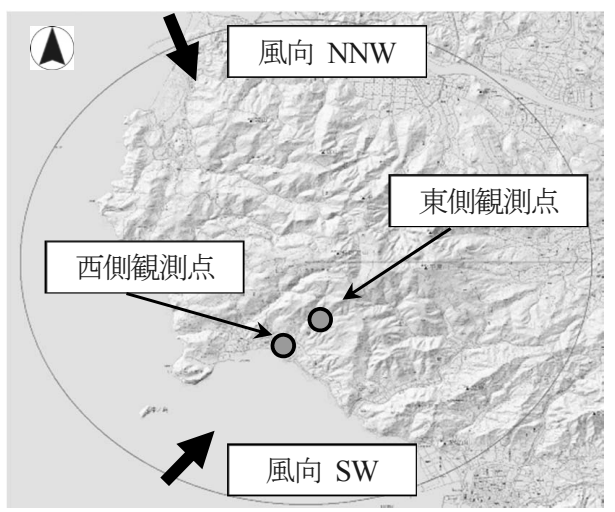

図 1 解析風向
表 1 ベンチマークテスト 1 の観測点概要

\begin{tabular}{|c|c|c|}
\hline 観測地点名 & 西側観測点 & 東側観測点 \\
\hline 緯度(北緯) & 31 度 46 分 37.3 秒 & 31 度 46 分 46.0 秒 \\
経度(東経) & 130 度 13 分 1.7 秒 & 130 度 13 分 32.8 秒 \\
\hline 標高 $(\mathrm{m})$ & 339 & 433 \\
\hline
\end{tabular}

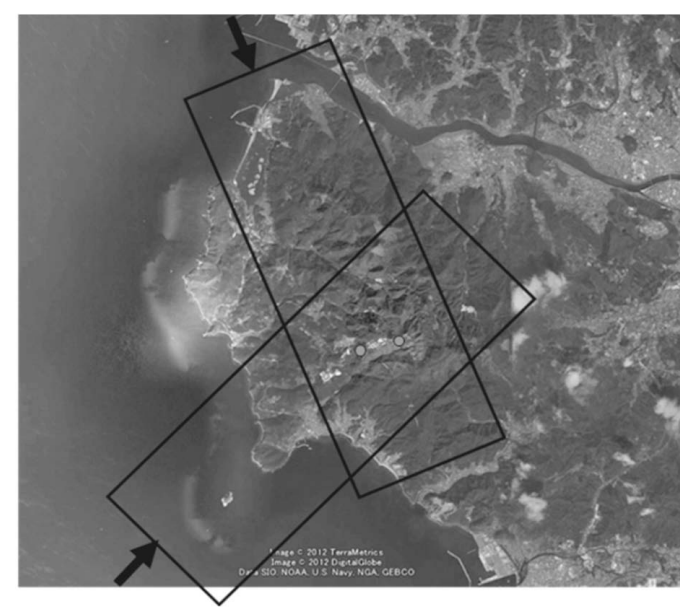

図 2 解析領域の航空写真

(2) 比較用データ

風向 NNW と風向 SW における比較用の解析結果の図 と, 比較する際のポイントを以下に示す。ここでは, 比 較用データとして，「LES（オープンソースコード）

-OpenFOAM」および「LES（自作）十メソ気象モデル WRF」の解析結果を用いている。

(1)平均風速コンター図

地表面高さ $60 \mathrm{~m}$ と $30 \mathrm{~m}$ の平均風速コンター図を図 3 に示す。(a)と(b)は風向 NNW，(c) と(d)は風向 SW におけ る結果である。これらの図を用いて, 平面的な平均風速 分布の傾向（増速領域および減速領域）を確認する。

風向 NNW においては, 両観測点の風上側に増速域が, 風下側に減速域が見られる。また風向 SW では, 両観測 点は増速域に含まれている。

(2)断面位置での標高と風速比

風向 NNW では西側観測点を含む断面，風向 SW では 東側観測点を含む断面における標高と地表面高さ $60 \mathrm{~m}$ と $30 \mathrm{~m}$ の風速比を図 4 に示す。なお，断面はそれぞれの 風向に沿っており，それぞれの観測点位置を流化方向距 離 $\mathrm{X}=0 \mathrm{~m}$ としている。断面位置を図 3 に合わせて示す。 また風速比は境界層高さにおける風速で無次元化してい る。風向 SW では観測点に向かって徐々に標高が高くな っているが，風向 NNW では観測点の風上側 $1200 \mathrm{~m}$ あた りに谷状の地形が見られる。 
両風向とも，尾根付近では風速比が増加しており，尾 根の背後の標高が低い部分では風速比が減少している傾 向が確認できる。また, 地表面高さ $30 \mathrm{~m}$ の方が高さ $60 \mathrm{~m}$ よりも地形に応じた風速比の変化の幅が大きく示されて いる。

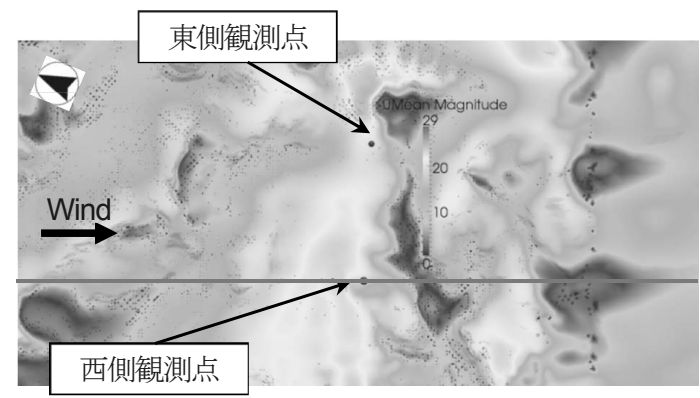

（a）地表面高さ $60 \mathrm{~m} ，$ 風向 $\mathrm{NNW}$

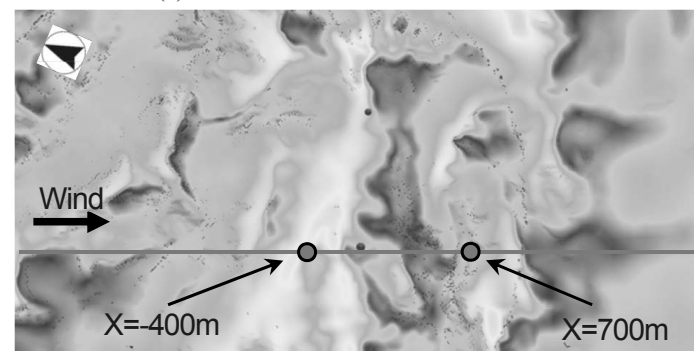

(b) 地表面高さ $30 \mathrm{~m}$ ，風向 $\mathrm{NNW}$

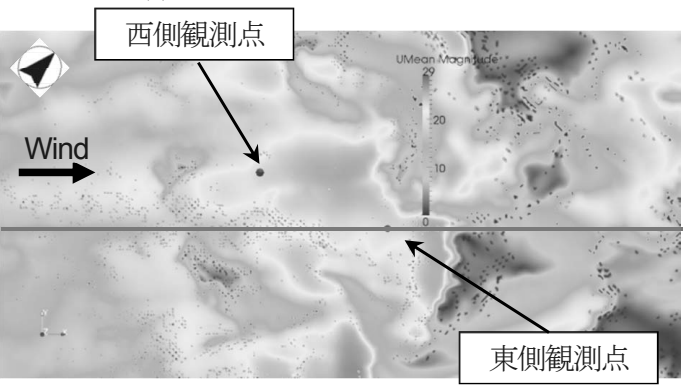

（c）地表面高さ $60 \mathrm{~m}$ ，風向 SW

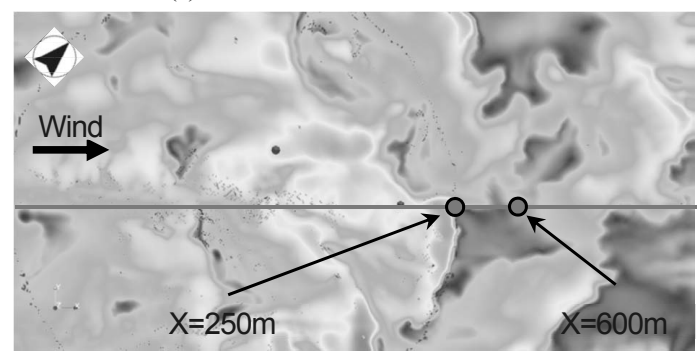

(d) 地表面高さ $30 \mathrm{~m}$ ，風向 SW

図 3 平均風速コンター図

(LES（オープンソースコード）-OpenFOAM)

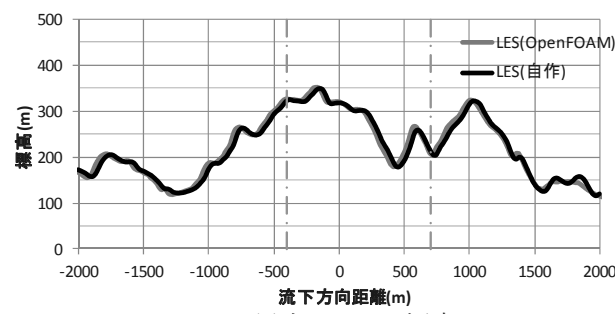

(a) 風向 NNW，標高

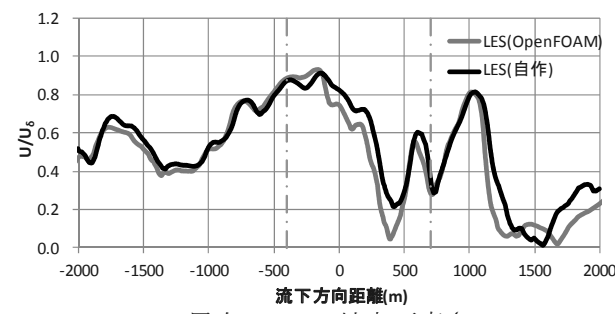

(b) 風向 NNW, 地表面高さ $60 \mathrm{~m}$

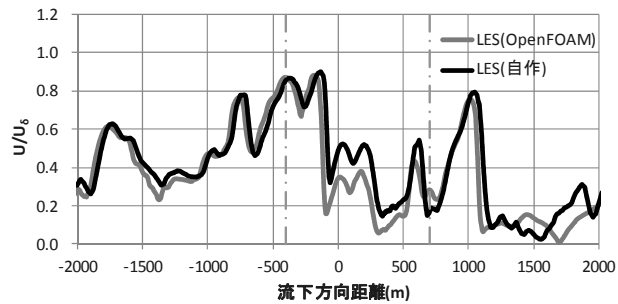

(c) 風向 NNW, 地表面高さ $30 \mathrm{~m}$

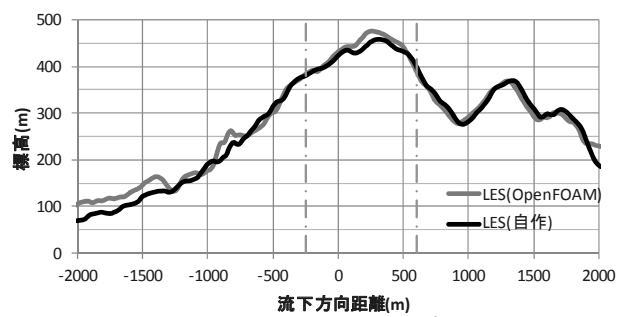

(d) 風向 SW，標高

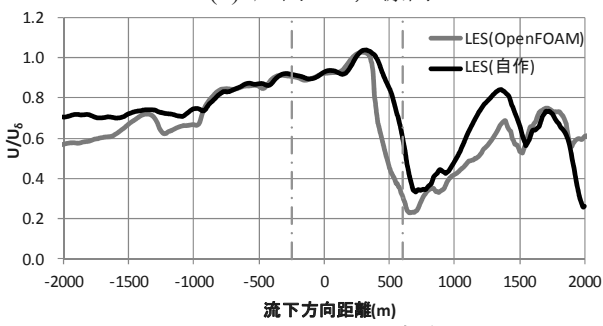

(e) 風向 SW, 地表面高さ $60 \mathrm{~m}$

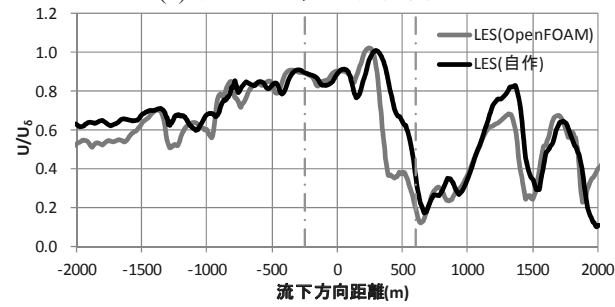

(f) 風向 $\mathrm{SW}$, 地表面高さ $30 \mathrm{~m}$

図4 断面位置での標高と風速比 


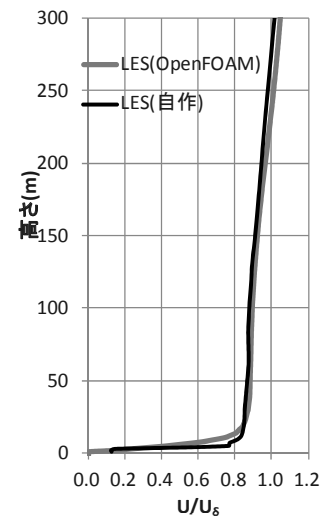

(a) 風向 $\mathrm{NNW}, \mathrm{X}=-400 \mathrm{~m}$

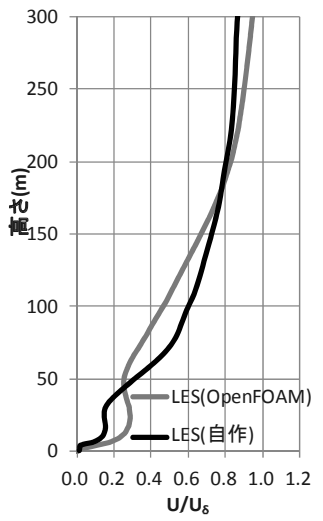

(b) 風向 $\mathrm{NNW}, \mathrm{X}=700 \mathrm{~m}$

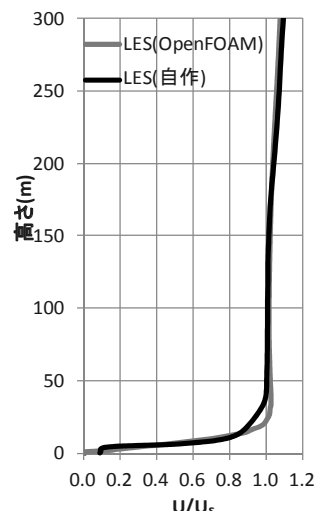

(c) 風向 $\mathrm{SW}, \mathrm{X}=250 \mathrm{~m}$

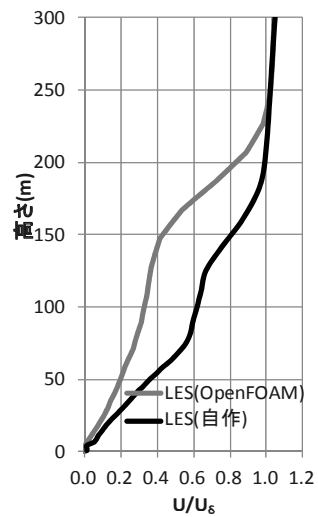

(d) 風向 $\mathrm{SW}, \mathrm{X}=600 \mathrm{~m}$

汹 5 断面位惪での鉛直プロファイル

(3)断面位置での標高と風速の鉛直分布

図 4 に示した断面において，増速域と減速域における 風速の鉛直分布を確認する。鉛直分布を求めた位置は, 風向 NNW では図 3(b)および図 4(b)(c) に示す $X=-400 \mathrm{~m}$ と $\mathrm{X}=700 \mathrm{~m}$ ，風向 SW では図 3(d)および図 4(e)(f)に示す $\mathrm{X}=250 \mathrm{~m}$ と $\mathrm{X}=600 \mathrm{~m}$ とし, 各位置における風速比の鉛直 分布を図 5 に示す。

図 5(a)および(c)に示すような標高が徐々に上がってい る尾根付近では地表面近傍まで増速傾向にあり, 図 5(b) および(d)に示すような尾根の背後の標高が低い部分で は地表面近傍で減速傾向にある。

\section{3 ベンチマークテスト 2 山口県白滝山 \\ (1) 解析条件}

解析対象は, 図 6 に示寸山口県白滝山地区とする。解 析結果の検証用となる観測点位置を. 図 6 に, 観測点の緯 度経度および標高を表 2 に示す。観測点は尾根上に位置 している。解析風向は, 図 6 に示寸風向 NE と寸る。こ の風向においては, 海岸線より入りこんで観測点に向け て徐々に地形が複雑化している。

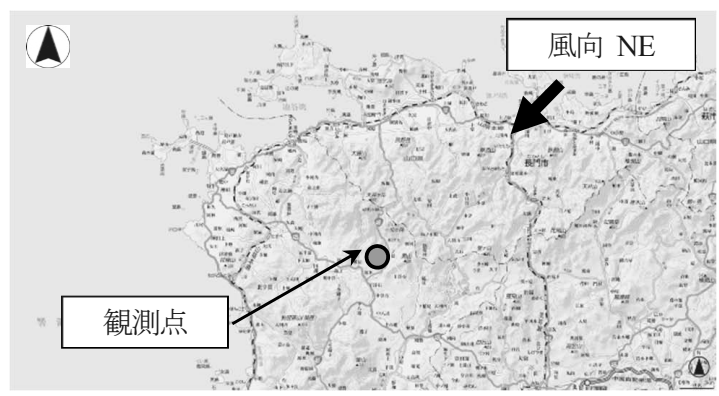

図 6 白滝山地区（地図出典 : プロアトラス SV5）
表 2 ベンチマークテスト 2 の観測点概要

\begin{tabular}{|c|c|}
\hline $\begin{array}{c}\text { 緯度(北緯) } \\
\text { 経度(東経) }\end{array}$ & $\begin{array}{c}34 \text { 度 } 18 \text { 分 } 14.5 \text { 秒 } \\
131 \text { 度 } 0 \text { 分 } 53.7 \text { 秒 }\end{array}$ \\
\hline 標高 $(\mathrm{m})$ & 580 \\
\hline
\end{tabular}

(2) 比較用データ

風向 NE における比較用の解析結果の図と, 比較する 際のポイントを以下に示す。なお, 比較用データとして は, すべて「LES (オープンソースコード) -OpenFOAM」 の解析結果を用いている。

(1)平均風速コンター図

地表面高さ $60 \mathrm{~m}$ と $30 \mathrm{~m}$ の平均風速コンター図を図 7 に示寸。これらの図を用いて, 平面的な平均風速分布の 傾向（増速領域および咸速領域）を確認する。尾根上の 観測点は増速域に含まれている。

(2)断面位置での標高と風速比

観測点を含む断面における標高と地表面高さ $60 \mathrm{~m}$ と $30 \mathrm{~m}$ の風速比を図 8 亿示寸。なお, 断面は風向に沿って おり, 観測点位置を流化方向距離 $\mathrm{X}=0 \mathrm{~m}$ としている。断 面位置を図 7 に合わせて示す。また風速比は境界層高さ における風速で無次元化している。観測点の風上側 $1200 \mathrm{~m}$ あたりに谷状の地形が見られるが，その後は尾根 上の観測点まで徐々に標高が高くなっている。

ベンチマークテスト 1 と同様に, 尾根付近では風速比 が増加しており, 尾根の背後の標高が低い部分では風速 比が減少している傾向が確認できる。また X=-450m およ び $X=-170 \mathrm{~m}$ あたりの位置に若干標高が低い部分が見ら れる。この領域において, 図 7(b)に示寸地表面高さ $60 \mathrm{~m}$ では風速比の変化の幅が小さいが, 図 7(c)に示寸地表面 高さ $30 \mathrm{~m}$ では地形の影響をより大きく受けて風速比の 変化の幅が大きく表れていることが分かる。 
(3)断面位置での標高と風速の鉛直分布

図 7 に示した断面において, 増速域と減速域における 風速の鉛直分布を確認する。鉛直分布を求めた位置は, 図 7(a)に示す $X=-1037 \mathrm{~m}$ と $X=3 \mathrm{~m}$ とし, 各位置における 風速比の鉛直分布を図 9 に示す。

ベンチマークテスト 1 と同様に, 図 9(b)に示すような 標高が徐々に上がっている尾根付近では地表面近傍ま で増速傾向にあり, 図 9(a)に示すような尾根の背後の標 高が低い部分では地表面近傍で減速傾向にある。

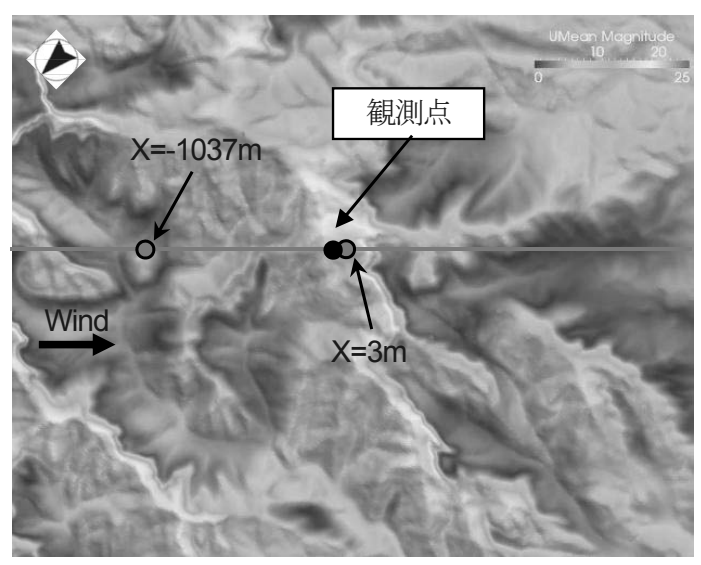

(a) 地表面高さ $60 \mathrm{~m}$

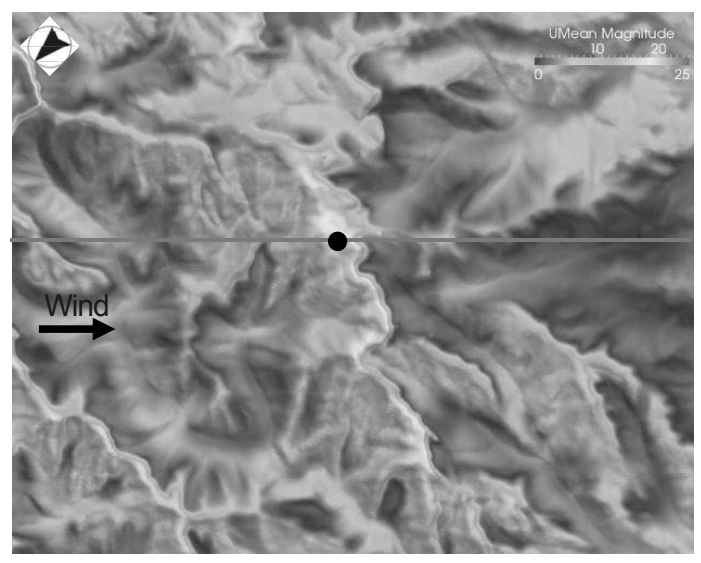

(b) 地表面高さ $30 \mathrm{~m}$

図 7 平均風速コンター図

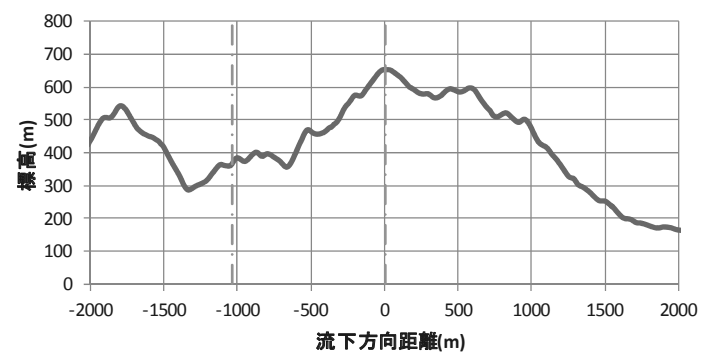

(a) 風向 NE，標高

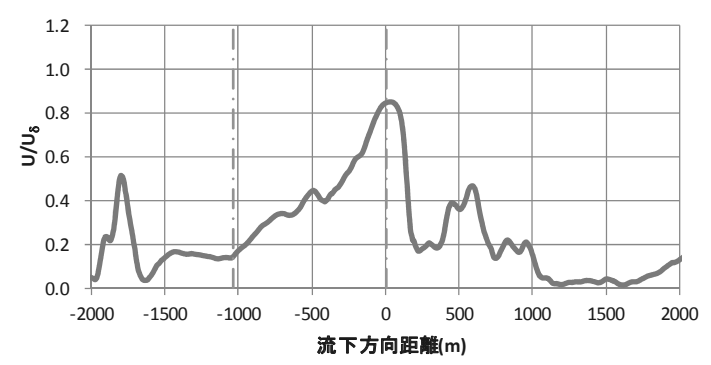

(b) 風向 NE，地表面高さ $60 \mathrm{~m}$

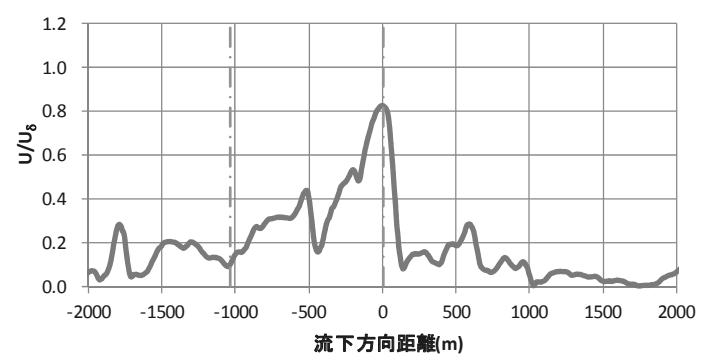

(c) 風向 NE，地表面高さ $30 \mathrm{~m}$

図 8 断面位置での標高と風速比
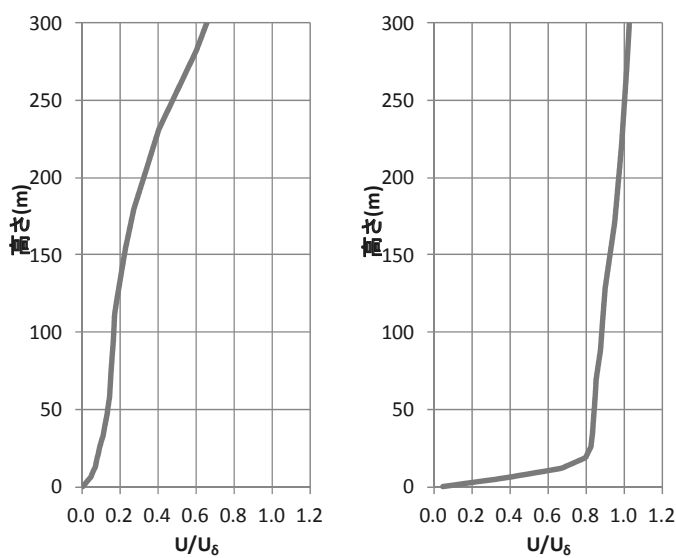

(a) 風向 $\mathrm{NNW}, \mathrm{X}=-1037 \mathrm{~m}$ (b) 風向 $\mathrm{NNW}, \mathrm{X}=3 \mathrm{~m}$,

困 9 断面位置での鉛直プロファイル 
3. 地形の影響を受けた風のデータベース

(岸田岳士)

建築物が地形の影響を受けて風が増速するような場所 に建てられる場合には風速の割り増しを何らかの方法で 考慮する必要がある。建築物荷重指針・同解説 1)では,

2 次元の傾斜地および尾根状地形を対象に平均および変 動風速の割り増しに関する資料が纒められている。而風 設計を実施する設計者は, 対象とする地形の起伏形態を 考慮して㿈められたデータから近い形状を選択して評価 を実施することとなる。この荷重指針に纏められた資料 は滑面の状態で実施した風洞実験に基づいたものであり, 風向については傾斜地や尾根状地形に直角に風が当たる 場合の実験結果である。一方，検討対象となる実在地形 の地表面の被覆形態は樹木が生い茂っていることもあり， その場合には地表近傍における風は樹木による粗度効果 を受けたものとなる。また，地形に対して必ずしも風が 直角に当たるとは限らないため, 風が地形に対し風向角 を持って流入するような場合も考慮に入れておく必要が ある。地形の影響を受けた風のデータベースを構築する うえで，こうした地表面の粗滑や風向角の影響も考慮す ることが重要である。

そこで本報では異なる地表面粗度, 風向角を有する単 純地形を対象にCFDにより風速の予測を実施し, 地表面 の粗滑および風向角が風に与える影響について検討を実 施する。そのうえで, CFD 解析結果に基づき地形の影響 を受けた風のデータベースの構築を行う。

\section{1 単純地形周りの CFD 解析結果の検討}

(1) LES による 3 次元孤立峰周りの解析 ${ }^{2)}$

地形上の風を対象とした CFD 解析の有効性を確認す

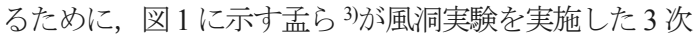
元孤立峰を対象に LES を実施し検証を行う。解析領域の 大きさは流下方向 $\times$ スパン方向 $\times$ 高さ方向 $=30 \mathrm{H} \times 30 \mathrm{H}$ $\times 15 \mathrm{H}$ とした。解析格子は非構造格子のメッシャーであ る NUMECA 社の HEXPRESS/Hybrid により作成した。 図 2 は表面メッシュで平坦な部分は四角形で, 丘陵地の 部分は三角形と四角形で構成されている。図 3 に示すよ うに大部分の解析格子は 6 面体(へキサ)で構成され, 地 表面に近づくほど倍ずつ格子は細かくなるように設定し ている。また, 地表近傍には 3 層の境界層要素を挿入し ている。

解析のソルバーにはオープンソースコードである

OpenFOAM(Ver1.7.1)を用いた。表 1 に解析条件の一覧を 示す。乱流モデルは標準型のスマゴリンスキーモデルと

し，地表面境界条件は滑面型および粗面型の対数則とし た。流入境界条件については準周期境界条件を用いた LES により別途作成して設定している。眓 4 に設定した 流入風の鉛直分布を比較対象とした風洞実験結果ととも に示す。縦軸は丘陵地高さ $\mathrm{H}$,横軸は丘陵地高さ $\mathrm{H}$ での風 速 $U_{H}$ で無次元化している。風洞実験結果と比較すると 平均, 変動成分ともにかなり良く一致していることが確 認できる。

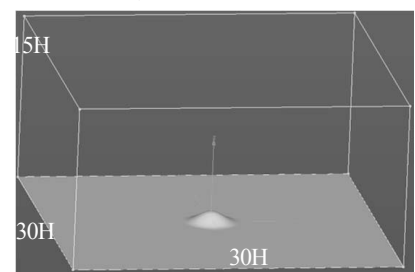

図 1 解析領域の概要

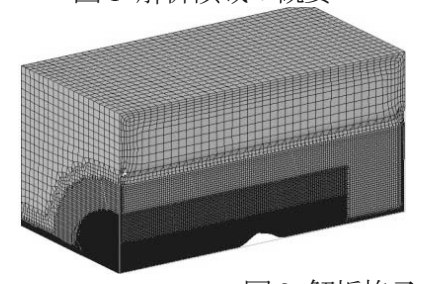

困 3 解析格子の概要 表 1 解析条件

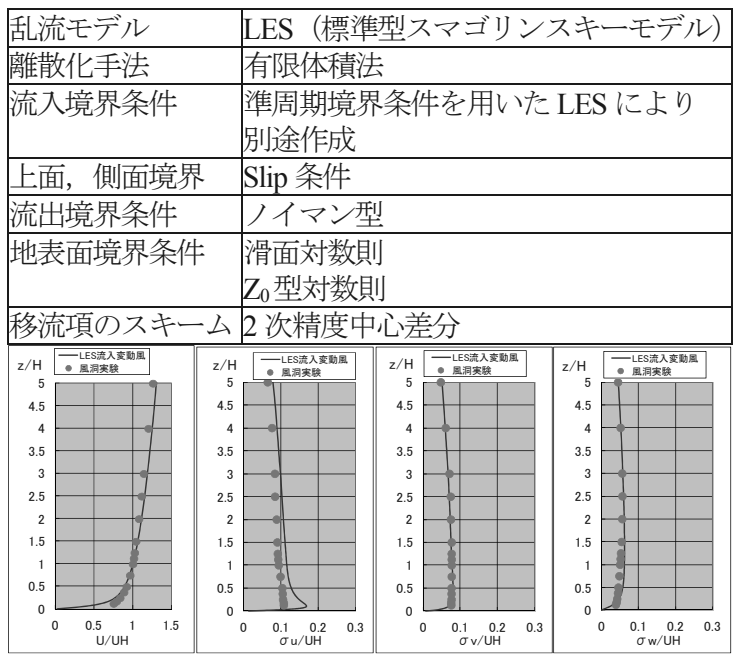

(a)滑面

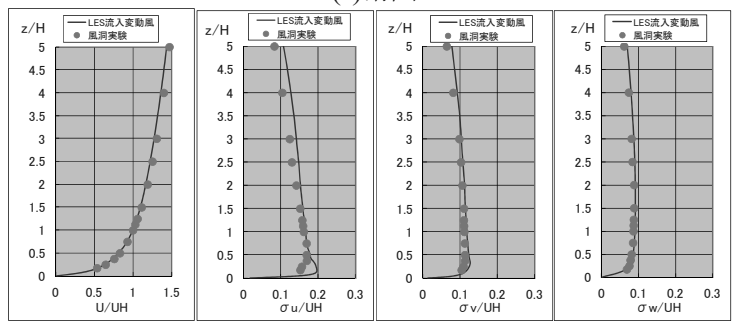

(b)粗面

図 4 流入風の鈆直分布

図 2 表面メッシュ

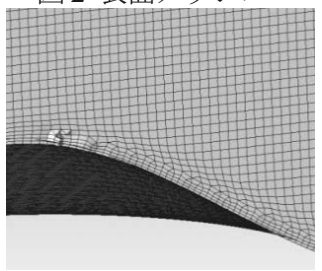
. 
図 5 および図 6 は丘陵地の中心断面における流れ方向 平均風速Uおよび流れ方向変動風速 $\sigma_{\mathrm{u}} / \mathrm{U}_{\mathrm{H}}$ の鉛直分布で あり, 図 5 は滑面, 図 6 は粗面の場合の結果である。平 均風速については滑面および粗面ともに風洞実験結果と 概ね良く一致している。丘陵地の後流に形成される循環 域の大きさは粗面のほうが大きくなるが LES の解析結 果でも良く再現されている。変動成分については粗面の $\mathrm{H}=1.25 \mathrm{H}$ の地表近傍で異なっているものの, 風洞実験結 果と概ねよく対応する分布となっている。

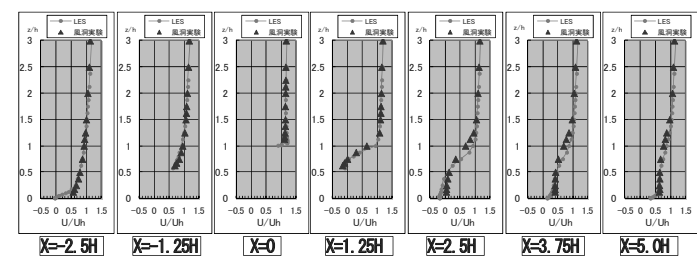

(a) 主流方向成分の平均風速

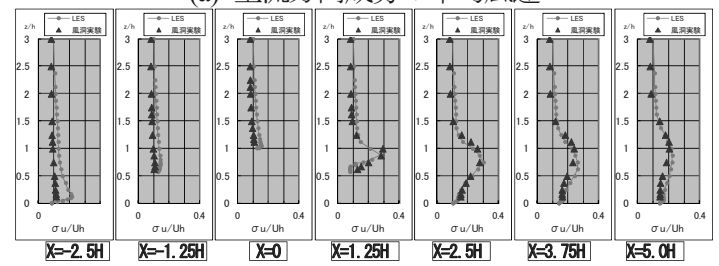

(b) 主流方向成分の変動風速

図 5 平均および変動風速の鉛直分布の比較(滑面)

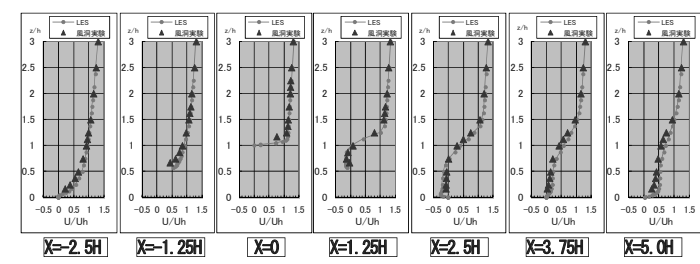

(a) 主流方向成分の平均風速

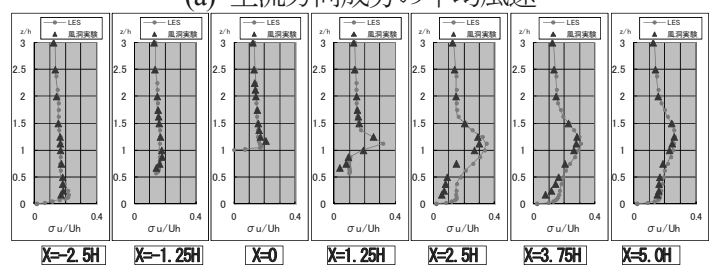

(b) 主流方向成分の変動風速

図 6 平均および変動風速の鉛直分布の比較(粗面)

(2) 粗度効果を考慮した 2 次元傾斜地周りの解析 ${ }^{2)}$

前節では 3 次元孤立峰の解析を実施し OpenFOAM に よる LES 解析モデルの有効性を示した。本節では, その 解析モデルを 2 次元傾斜地モデルに適用して検討を行う。 検討ケースは表 2 に示寸ように傾斜角は $15^{\circ}$ と $30^{\circ}$ の 2
通り，地表面粗度は滑面と粗面の 2 通りで計 4 ケースの 検討を実施した。流入境界条件などの解析条件の設定や 格子生成法については 2.1 節と同様の方法とした。

表 22 次元傾斜地を対象とした検討ケース

\begin{tabular}{|c|c|c|}
\hline & 傾斜角 & 地表面粗度 \\
\hline Case-1 & $15^{\circ}$ & 滑面 \\
\hline Case-2 & $15^{\circ}$ & 粗面 \\
\hline Case-3 & $30^{\circ}$ & 滑面 \\
\hline Case-4 & $30^{\circ}$ & 粗面 \\
\hline
\end{tabular}

図 7 に傾斜角 $15^{\circ}$, 図 8 に傾斜角 $30^{\circ}$ の流下方向成 分の平均風速Uのコンター図を示す。風速值はそれぞれ, 傾斜地の影響を受けていない上流側の傾斜地高さHの風 速 $U_{H}$ で無次元化されている。図 7 の傾斜角 $15^{\circ}$ では, 滑面・粗面ともに傾斜地頂上近傍の領域で風速が大きく なるのは同様の傾向であり, 傾斜地の上部では, Case-2 の粗面のほうが地表近傍の減速領域の層がやや厚くなっ ているのがわかる。なお, Case-2 の粗面の場合には傾斜 地頂上部より下流での減速領域が滑面より大きいものの 逆流域は形成していない。図8の傾斜角 $30^{\circ}$ の場合には, 頂部近傍の領域で風速が強くなることや滑面より粗面の ほうが丘陵地上部の地表近傍の風速の減速領域の層が厚 いことは同様の傾向となるが, Case-4 の粗面の場合には 傾斜地の頂部から後流側に逆流領域がみられ, 流れが丘 陵地頂部で剥離している様子がわかる。傾斜角の違いに 着目すると，傾斜角が $30^{\circ}$ のほうが $15^{\circ}$ の場合よりも 傾斜地上部の増速領域では風速が大きくなることがわか る。また, 滑面の場合 (Case-1 と Case-3) では傾斜頂部 より下流側の風速分布は, 減速領域の厚さなどほとんど 差が見られないが, 粗面の場合 (Case-2 と Case-4) では Case-4 では剥離を伴うために異なる流況となり, Case-4 のほうが地表近傍の風速の減速領域の厚みが大きくなっ ている様子がわかる。

図9は傾斜角 $15^{\circ}$ の場合の風速の増速率の鉛直分布の 比較である。地表面の傾斜の影響により流れが収束して 風速が増速することになり, 丘陵地の頂部で滑面および 粗面ともに増速率は最も大きくなる。また, 増速率は粗 面の方が滑面よりも大きくなっている。 $\mathrm{X} / \mathrm{H}=1$ よりも下 流側に着目寸ると, 粗面の場合には高さ $\mathrm{z} / \mathrm{h}=1.2$ あたりに 増速率のピークがみられる。これは, 図7で示したよう に, 粗面では地表近傍で風速の減速領域が厚くなってお り，粗面の場合には滑面よりも上層で流れが収束するこ とになることから，その部分で風速の増速率が大きくな っていると考えられる。図 10 の傾斜角 $30^{\circ}$ の場合にも 
似た傾向となっており, 流れが剥離している $\mathrm{X} / \mathrm{H}=1$ およ びX/H=2 の地表近傍では増速率が小さくなるが, その減 速部分の上部では粗面の増速率の方が大きくなっている。 傾斜角の違いに着目寸ると, 頂上部付近 $(\mathrm{X} / \mathrm{H}=0)$ では傾斜 角の大きいほうが増速率は大きくなる。図 11 に粗面の増 速率と滑面の増速率の比を示す。滑面よりも粗面のほう が増速率が大きくなることが確認できる。 $\mathrm{X} / \mathrm{H}=1$ に着目 すると傾斜角の違いにより異なる傾向となるが, 傾斜角 $30^{\circ}$ の場合には滑面では $\mathrm{z} / \mathrm{H} \doteqdot 1.1$, 粗面の場合には z/H $\fallingdotseq 1.3$ より上空では滑面より粗面の方が増速率の比が大 きくなることになる。これは, 対象とする建築物の大き さと地形の大きさとの関係により影響範囲は変化するこ とになるが，これまでには考慮されていなかった粗面の 方が滑面よりも増速率が大きくなる場合があることを示 している。

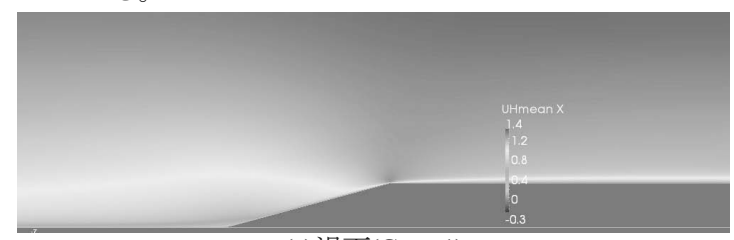

(a)滑面(Case-1)

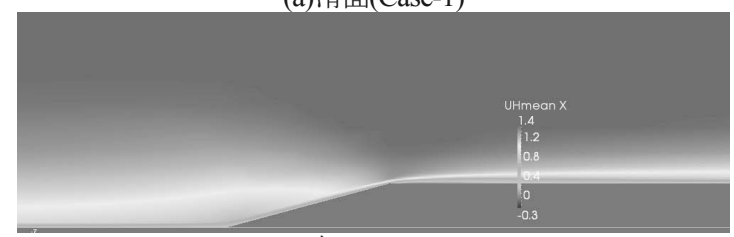

(b)粗面(Case-2)

困 7 平均風速のコンター図(傾斜角 $15^{\circ}$ )

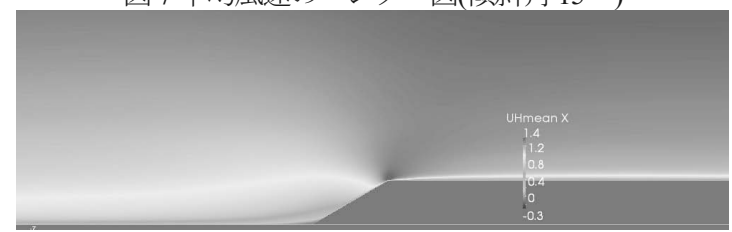

(a)滑面(Case-3)

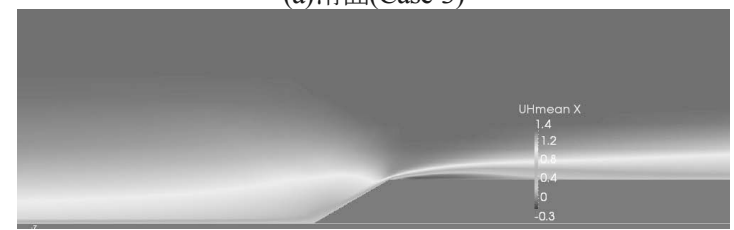

(b)粗面(Case-4)

図 8 平均風速のコンター図(傾斜角 $30^{\circ}$ )

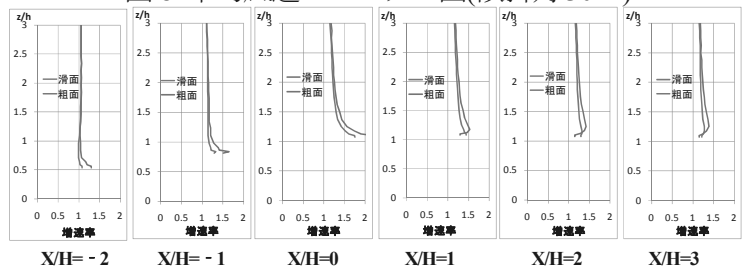

図 9 増速率の鉛直分布の比較(傾斜角 $15^{\circ}$ )
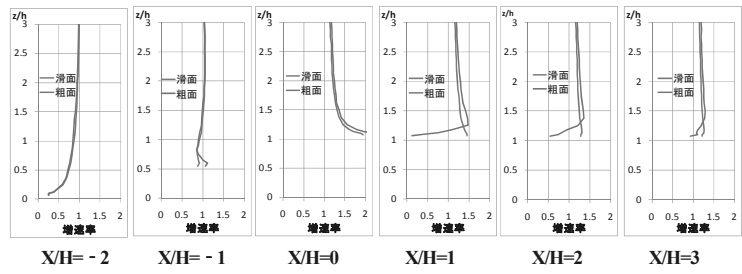

図 10 増速率の鉛直分布の比較(傾斜角 $30^{\circ}$ )

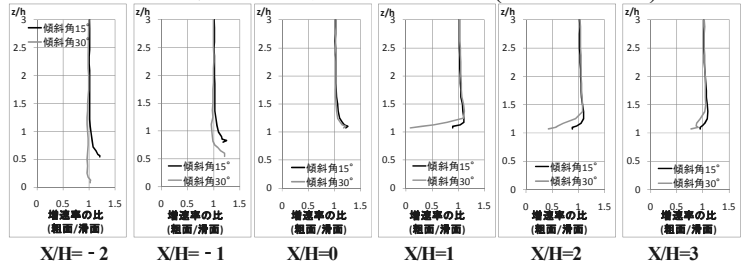

図 11 粗面の増速率と滑面の増速率の比の鉛直分布

(3) 風向角を有する 2 次元傾斜地周りの解析 ${ }^{4)}$

本節では 2 次元傾斜地に対し風が風向角を有して流入 する場合を対象に検討を行う。而風設計を実施する日本 の地形の起伏はかなり複雑な形状となっており, 地形に 対して必ずしも直角に風が当たるとは限らない。特に, 剥離を伴うような急峻な地形に風が風向角を持って流入 寸る場合にはかなり複雑な流れ場が形成されることが予 想され，風速の増速を評価するうえではこうした場合の 風況を把握しておくことが重要であると考えられる。

前節までは LES による予測を対象に議論を進めてき たが, 地形周りを対象とした CFDによる風速予測はこれ までに計算負荷の低いRANS モデルでも多く害施されて きた。工学の分野では多くの場面で使われ実績のある標 準型 $\mathrm{k}-\varepsilon$ モデルでは, 本報の検討対象のように剥離を伴 うような急峻で複雑な地形を対象とした場合には適切に 予測できない場合があることも想定される。そこで本節 では, 剥離をともなうような急峻な地形に風が風向角を 持って流入する場合を対象に検討を行う。データベース の作成を念頭に置き計算負荷の低いRANS モデルによる 解析を実施することとし，複雑な流れ場でも予測精度の 確保が期待される修正型のRANS モデルにより検討を実 施する。また，前節までと同様の LES についても併せて 実施して検証を行う。

解析のソルバーは OpenFOAM Ver2.1.1 とした。乱流モ デルは，急峻な地形にみられるような非等方性の強い流 れ場でも精度の確保が期待される, 非線形モデルの Shih のモデル5)を採用した。さらに, 衝突流で乱流エネルギ 一 $\mathrm{k}$ の過剩生成する従来の課題に対して精度の向上が期 待される Kato-Launder 補正を併せて適用することとした。 なお，境界面では乱流エネルギーの過大評価を防ぐため 
に生成項Pkを修正して対応するアルゴリズムのを補強し ている。

解析格子は図 12 に示すように, 前節と同様な方法で作 成している。検討対象とした傾斜地は, 剥離を伴うよう な急峻な地形に対して風向角を持って風が流入して複雑 な流れ場を形成するような場合を検討するために傾斜角 を $75^{\circ}$ ，風向角を $45^{\circ}$ とした。

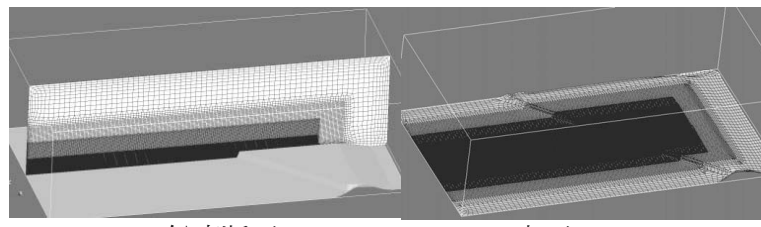

(a)鉛直断面 図 12 解析格子の設定

図 13 にLES による解析結果を示寸。(a)は高さ $1.25 \mathrm{H}$ におけるスパン方向( $\mathrm{Y}$ 方向)成分風速 $\mathrm{V}$ の瞬間場である が, 崖地の頂上部付近で複雑な乱流構造となっている様 子が見られ, $\mathrm{Y}$ 方向負の成分の風速を持っている。(b)は 平均場の流線であるが，崖地の頂部では崖地の形状に沿 う方向へのらせん状の流れが確認できる。一方，図 14 はRANS による解析結果であるが, (a)標準 k- $\varepsilon$ モデルで は LES と異なり崖地の上部で主流方向(X 方向)へとその まま流下している。(b)の修正型 RANS では LES と近い 流れ場となり，らせん状に流れていく様子がわかる。

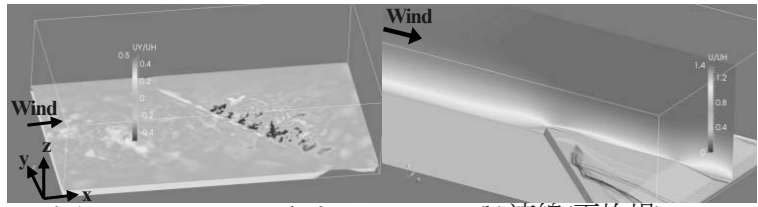

(a)高さ $1.25 \mathrm{H}$ のスパン風速瞬間場 $\quad$ (b)流線(平均場)
図 $13 \mathrm{LES}$ の解析結果(傾斜角 $75^{\circ}$ ，風向 $45^{\circ}$ )

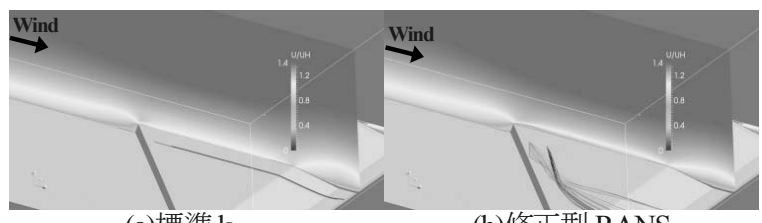

(a)標準 k- $\varepsilon \quad$ (b)修正型 RANS

図 14 RANS 解析結果(傾斜角 $75^{\circ}$, 風向 $45^{\circ}$ )

図 15 は傾斜角 $75^{\circ}$ ，風向 $0^{\circ}$ における流下方向成分 風速の比較である。標準 $\mathrm{k}-\varepsilon$ では崖地上部の $\mathrm{X} / \mathrm{H}=1$ より 後流側で LES とはかなり異なった結果となり, 循環域が 形成されていない。修正型 RANS では X/H=3 より後流 で風速の減速が LES よりも大きくなっているものの, $\mathrm{X} / \mathrm{H}=1$ および 2 ではLES の結果と良く対応している。図
16 の傾斜角 $75^{\circ}$ ，風向 $45^{\circ}$ の場合の結果をみると，標 準k- $\varepsilon$ ではLES とはかなり異なった結果であるが, 修正 型RANS では流下方向成分およびスパン成分ともにLES とかなり良く対応した分布となる。(b)のスパン方向成分 風速の $\mathrm{X} / \mathrm{H}=1$ の分布は，地表近傍では負の成分，それよ り上空では正の成分で下層と逆向きとなる特徵的な分布 となっているが, 修正型 RANS は LES と同様の分布形 状となっている。図 17 に風向 $0^{\circ}$ と $45^{\circ}$ の水平方向成 分風速の比較を示す。風向 $45^{\circ}$ の場合には流下方向およ びスパン方向の水平 2 成分のスカラー風速である。

$\mathrm{X} / \mathrm{H}=1$ の分布をみると風速が地形の影響により増速され， 高さ $\mathrm{Z} / \mathrm{H}=1.5$ 付近では風向 $0^{\circ}$ のほうが風速は強くなっ ている。これは，風向角を有する場合には相対的に地形 の傾斜角が小さくなるためと考えられる。一方，Z/H が 1.5 より低い場合には風向 $45^{\circ}$ の方が風速は強くなって いることがわかり，増速は風向 $0^{\circ}$ の方が必ずしも大き くなるとは限らないことを示している。
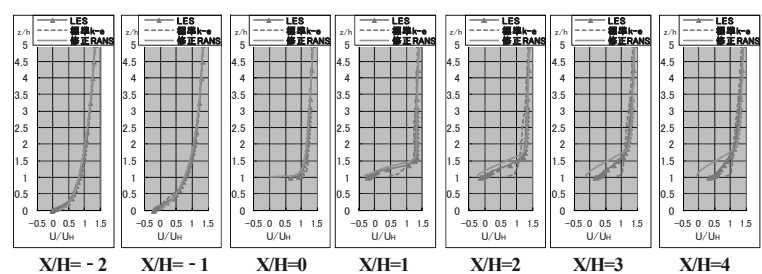

図 15 風向 $0^{\circ}$ における流下方向成分風速の比較
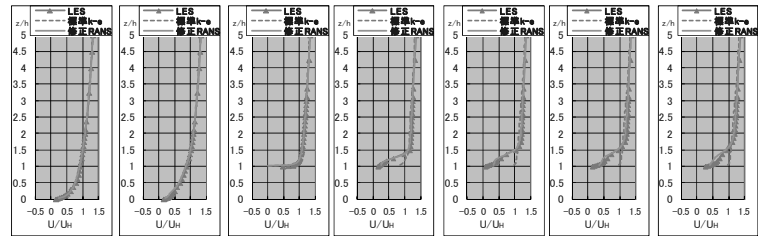

(a)流下方向成分 U
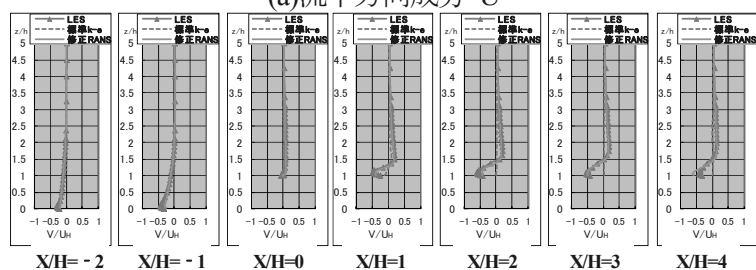

(b)スパン方向成分風速 $\mathrm{V}$

図 16 風向 $45^{\circ}$ における流下・スパン方向成分風速の比較
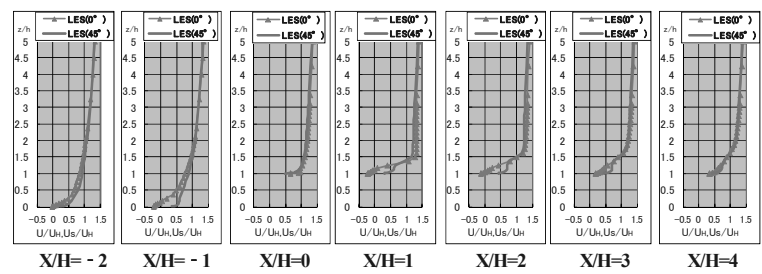

図 17 風向 $0^{\circ}$ と風向 $45^{\circ}$ の水平方向成分風速の比較 
3. 2 単純地形の風速の割増に関するデータベース7

表 3 に単純地形として選定したデータベースのケース を示す。風速の増速が顕著でかつ実際の地形に対して適 用する際にあてはめやすい形状を考慮して 2 次元の傾斜 地および 3 次元の孤立峰とした。また，(2)の検討におい て, 地表面の被覆形態の違いにより解析結果が異なり, 風速の増速率も変化するため, 風向角 $0^{\circ}$ の傾斜地およ び 3 次元孤立峰では, 滑面および粗面の 2 種類とした。 また, 風向角については傾斜角 $30^{\circ}$ を対象に, 風向角 $15^{\circ}, 30^{\circ}, 45^{\circ}$ および $60^{\circ}$ としたケースも実施して単 純地形における流入風の風向角の影響についても検討を 行つた。

データベースの作成は，(3)で検討を実施した修正型 RANS モデルの解析結果により行うこととした。流入境 界条件の設定は図 4 に示す分布と同様とし, 滑面の場合 にはべき指数 $\alpha \fallingdotseq 0.15$, 粗面の場合には $\alpha \fallingdotseq 0.25$ となっ ている。図 18 に傾斜角 $30^{\circ}$ の 2 次元傾斜地の壁面近傍 の解析格子を示す。壁面近傍には 3 層の境界層要素が挿 入され, 壁面第一層の鉛直方向格子解像度は約 $0.065 \mathrm{H}$ で ある。

表 3 単純地形のデータベース

\begin{tabular}{|c|c|c|c|c|c|c|c|}
\hline \multirow{2}{*}{\multicolumn{3}{|c|}{$\begin{array}{l}\text { 地形パターン } \\
\text { 風向角 }\left(^{\circ}\right)\end{array}$}} & \multicolumn{5}{|c|}{ 傾斜地 } \\
\hline & & & 0 & 15 & 30 & 45 & 60 \\
\hline \multirow{10}{*}{$\begin{array}{l}\text { 傾斜 } \\
\text { 角 } \\
\text { 。 }\end{array}$} & \multirow{2}{*}{7.5} & 滑面 & 0 & & & & \\
\hline & & 粗面 & 0 & & & & \\
\hline & \multirow{2}{*}{15} & 滑面 & 0 & & & & \\
\hline & & 粗面 & 0 & & & & \\
\hline & \multirow{2}{*}{30} & 滑面 & 0 & 0 & 0 & 0 & 0 \\
\hline & & 粗面 & 0 & & & & \\
\hline & \multirow{2}{*}{45} & 滑面 & 0 & & & & \\
\hline & & 粗面 & 0 & & & & \\
\hline & \multirow[b]{2}{*}{60} & 滑面 & 0 & & & & \\
\hline & & 粗面 & 0 & & & & \\
\hline
\end{tabular}

\begin{tabular}{|c|c|c|}
\hline 高さ & 地表面 & 孤立峰 \\
\hline \multirow{2}{*}{$\mathrm{H} / 4$} & 滑面 & 0 \\
\hline & 粗面 & 0 \\
\hline \multirow{2}{*}{$\mathrm{H} / 2$} & 滑面 & 0 \\
\hline & 粗面 & 0 \\
\hline \multirow{2}{*}{$\mathrm{H}$} & 滑面 & 0 \\
\hline & 粗面 & 0 \\
\hline & & \\
\hline & & \\
\hline & & \\
\hline
\end{tabular}

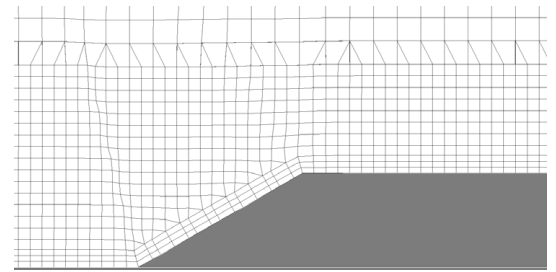

図 18 壁面近傍の解析格子(2 次元傾斜地，傾斜角 $30^{\circ}$ )

図 19 にデータベースの 1 例として, 傾斜角 $30^{\circ} 2$ 次 元傾斜地の増速率を示す。増速率は, 各地点の風速を流 入気流の同一高さの風速で基準化した值である。風向角 の影響についてみると, 風向角が大きくなると風速の増 速率は減少している。風向角が $45^{\circ}$ の場合, 流入風の流 下方向断面の傾斜角は $22.2^{\circ}$ となり $30^{\circ}$ よりも緩やか になるため, 風速の増速率は減少していると考えられる。 なお, ここでは示さないが傾斜角 $30^{\circ}$ の場合には風向角 が増すにつれて風速の増加率は減少する傾向となり, 風 向角 $0^{\circ}$ の場合が最も大きくなっている。ただし 2.3 節
で検討したように，かなり急峻な傾斜角を有する地形に 風が斜めから流入し複雑な流れ場となる場合には，地表 近傍において必ずしも風向角 $0^{\circ}$ のほうが大きくならな い場合もあるので注意を要する。地表面の粗滑に着目寸 ると，滑面よりも粗面のほうが増速率は大きくなる。

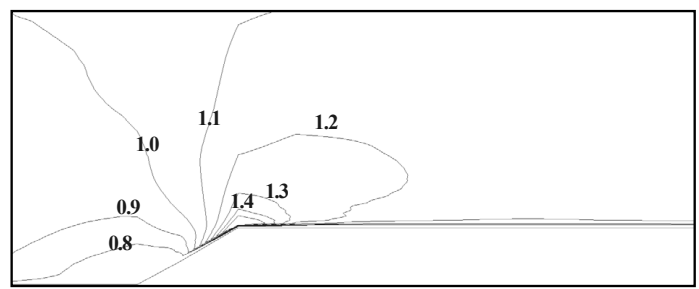

(a)傾斜角 $30^{\circ}$ (滑面，風向 $\left.0^{\circ}\right)$

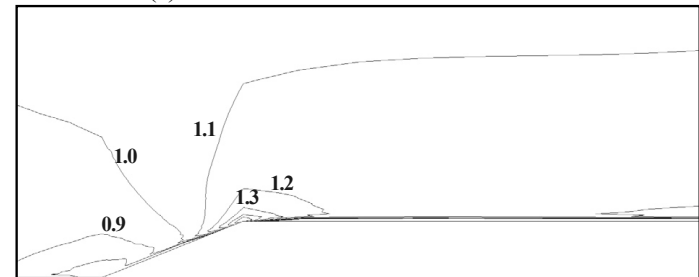

(b)傾斜角 $30^{\circ}$ (滑面, 風向 $45^{\circ}$ 流下方向の傾斜角 $22.2^{\circ}$ )

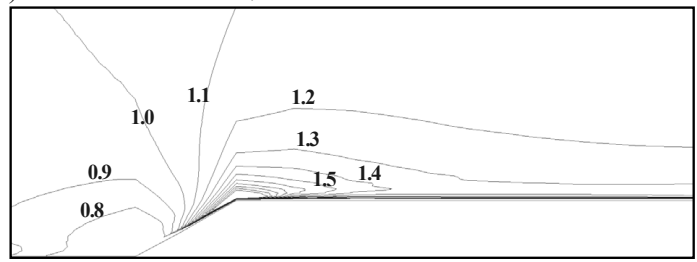

(c)傾斜角 $30^{\circ}$ (粗面, 風向 $0^{\circ}$ )

図 192 次元傾斜地の増速率のコンター図

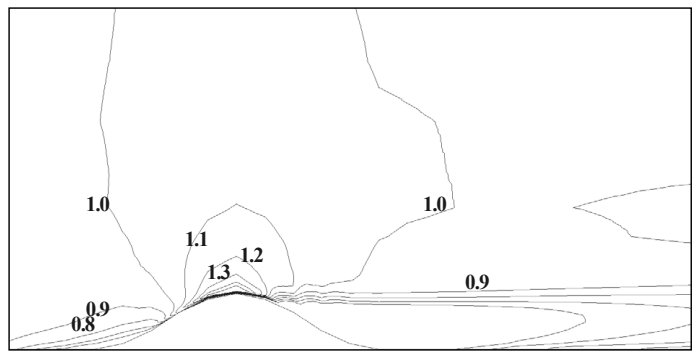

(a)滑面 高さH

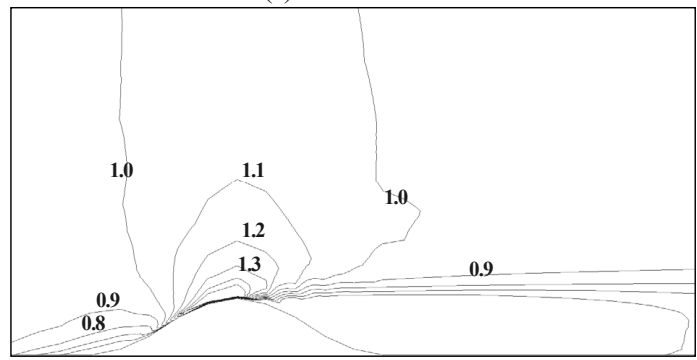

(b)粗面 高さ $\mathrm{H}$

図 203 次元孤立峰の増速率のコンター図 
図20に3次元孤立峰の中心断面における増速率を示す。 増速率の分布のパターンは 2 次元傾斜地とおおよそ似て おり頂部付近で最も大きくなる。また， 2 次元傾斜地同 様に滑面より粗面の方が大きくなっている。

\section{3 まとめ}

本節では, まず始めに風洞実験結果との比較により地 形上の風に対する LES 解析モデルの予測精度の確認を 行った。また, 修正型RANS モデルを地形上の風の予測 に適用することの妥当性を示した。そのうえで, 地表面 の粗滑が風に与える影響らなびに風が地形に対して風向 角を有して流入する場合の影響についての検討を行った。 地表面の粗滑の影響は, 滑面よりも粗面の方が増速率が 大きくなることを示した。また，風向角の影響は傾斜角 $30^{\circ}$ の場合には正対風向の $0^{\circ}$ が最も増速率が大きく, 風向角が大きくなるほど増速率は小さくなった。ただし， 流れが剥離したりらせん状の流れとなるような急峻な地 形の場合には必ずしも正対風向が大きくなるとは限らな い可能性があるため, 今後さらに検討をする必要がある。 最後に, CFD 解析結果に基づき地形の影響を受けた風の データベースの構築を行った。
参考文献

1) 日本建築学会, 「建築物荷重指針・同解説」,(2004)

2) 岸田 岳士, 田村 哲郎, 「粗度効果を考慮した単純地 形周りの流れの CFD $\rfloor$, 第 27 回数值流体力学シンポ ジウム, (2013.12)

3) 孟 岩, 日比一喜, 「急峻な山を越える乱流境界層に 関する実験的研究」, 第 15 回風工学シンポジウム論 文集, pp. 61-66, (1998)

4) 岸田 岳士, 田村 哲郎, 「傾斜地周りの風に対寸る修 正型 RANS の適用」, 日本建築学会学術講演梗概集, (2014.8)

5) Shih, T.H., et al., "A new Reynolds stress algebraic equation model", Computer methods in applied mechanics and engineering, 125, pp. 287-302, (1995)

6) 石原 孟, 日比一喜, 「急峻な山を越える乱流場の数 值予測」, 日本風工学会誌, 第 83 号, pp. 175-188, (2000.4)

7) 中村, 田村ら,「風速の地形による影響評価に関する 検討 その 3 データベースの実地形への適用」, 日本 建築学会学術講演梗概集, (2013.8) 